The successor to the journal Music Review, Nineteenth-Century Music Review aims to locate music within the widest possible framework of intellectual activity pertaining to the long nineteenth century (c.1789-1914). It particularly welcomes interdisciplinary scholarship that explores music within the context of other artistic and scientific discourses. Articles with fine visual or iconographic content are encouraged, as are those rich in musically illustrative material. Articles accepted for publication will reflect a diversity of critical viewpoints.

\title{
Contents of Volume 4, Issue 1
}

Articles

Brian Alegant and On the Nature of Structural Framing

Don McLean

Anastasia Siopsi

Theorizing 'Death': The Meaning of Negation as a Hegelian Inheritance in Richard Wagner's Musik als Idee

Marian Wilson Kimber Victorian Fairies and Felix Mendelssohn's A Midsummer Night's Dream in England

Thomas Muir

'Old Wine in New Bottles': Renaissance Polyphony in the English Catholic Church during the Nineteenth and Early Twentieth Centuries

Donald C. Seibert The Enchantress and Problems of Pacing in the Operas of Tchaikovsky: An Informal Interview with David Lloyd-Jones

Review Article
Byron Adams
Elgar Studies

Book Reviews

CD Reviews

Score Reviews

Published in association with the Centre for Nineteenth-Century Music, Durham University, UK

Cover illustration: 'Behind the Scenes - up to the Flies - Gauzy Nymphs going up to the Gridiron to Descend to Earth', from The Day's Doings, 31 December 1871.

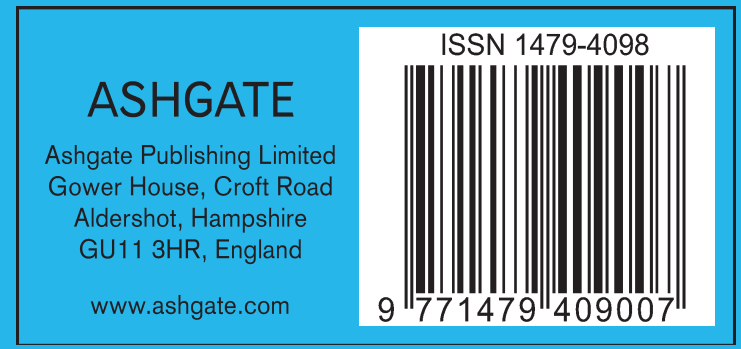

